\title{
Detecting influenza-associated pulmonary aspergillosis by determination of galactomannan in broncho-alveolar lavage fluid and in serum: should we add $(1,3)$ - beta-D-glucan to improve efficacy
}

\author{
Patrick M. Honore*, Leonel Barreto Gutierrez, Luc Kugener, Sebastien Redant, Rachid Attou, Andrea Gallerani and \\ David De Bels
}

We read with great interest the recent research letter by Thevissen et al. who reported the findings of their international survey regarding the detection of influenzaassociated pulmonary aspergillosis (IAPA), with a focus on the use of galactomannan (GM) in broncho-alveolar lavage (BAL) fluid and serum [1]. They note that greater awareness of IAPA is needed, as are rapid diagnostic tests [1]. We would like to make some comments. Indeed, over the past decades, the patient population having invasive aspergillosis (IA) or IAPA risk factors has expanded significantly, and given that IA/IAPA is associated with high morbidity and mortality, improved diagnostic modalities are required [2]. GM is currently a commonly used method and has a high specificity for IA/IAPA diagnosis, while another test, the $(1,3)$-beta-Dglucan (BDG) assay, has a high negative predictive value (NPV), making it quite useful to rule out IA/IAPA rather than to confirm it $[2,3]$. GM and BDG assays can play an important role in IA/IAPA diagnosis in nonneutropenic patients with underlying respiratory diseases without hematologic malignancy [2]. BDG is the most important and abundant polysaccharide component of the cell wall of most fungi. While incorporated within the fungal cell wall, BDG typically exists as an insoluble structure. In the presence of blood or other body fluids, it transforms into single helix, triple helix (most

\footnotetext{
* Correspondence: patrick.honore@chu-brugmann.be

ICU Department, Centre Hospitalier Universitaire Brugmann-Brugmann

University Hospital, Place Van Gehuchtenplein, 4, 1020 Brussels, Belgium
}

commonly), or random coil forms and is rendered soluble [4]. The GM assay has been found to be more specific than BDG (97\% versus $82 \%)$ and BDG more sensitive than GM ( $81 \%$ versus $49 \%$ ), suggesting that a combination of both tests could strengthen the diagnosis of IA/IAPA [3]. We would like to conclude that GM was found to have high diagnostic specificity, while BDG displayed better sensitivity. Either test used alone carries a certain level of diagnostic limitation. A combination of both assays would improve the diagnostic capacity.

\begin{abstract}
Abbreviations
IAPA: Influenza-associated pulmonary aspergillosis; GM: Galactomannan; BAL: Broncho-alveolar lavage; IA: Invasive aspergillosis; BDG: (1,3)-Beta-Dglucan
\end{abstract}

\section{Acknowledgements \\ We would like to thank Dr. Melissa Jackson for critical review of the manuscript.}

\begin{abstract}
Authors' contributions
$\mathrm{PMH}, \mathrm{SR}$, and DDB designed the paper. All authors participated in drafting and reviewing. All authors read and approved the final version of the manuscript.
\end{abstract}

\section{Funding}

None.

\begin{abstract}
Availability of data and materials Not applicable.
\end{abstract}

Ethics approval and consent to participate Not applicable.

\section{Consent for publication \\ Not applicable.}

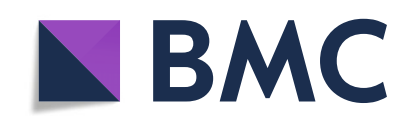

(c) The Author(s). 2020 Open Access This article is licensed under a Creative Commons Attribution 4.0 International License, which permits use, sharing, adaptation, distribution and reproduction in any medium or format, as long as you give appropriate credit to the original author(s) and the source, provide a link to the Creative Commons licence, and indicate if changes were made. The images or other third party material in this article are included in the article's Creative Commons licence, unless indicated otherwise in a credit line to the material. If material is not included in the article's Creative Commons licence and your intended use is not permitted by statutory regulation or exceeds the permitted use, you will need to obtain permission directly from the copyright holder. To view a copy of this licence, visit http://creativecommons.org/licenses/by/4.0/ The Creative Commons Public Domain Dedication waiver (http://creativecommons.org/publicdomain/zero/1.0/) applies to the data made available in this article, unless otherwise stated in a credit line to the data. 


\section{Competing interests}

The authors declare that they have no competing interests.

Received: 11 May 2020 Accepted: 26 May 2020

Published online: 05 June 2020

\section{References}

1. Thevissen K, Jacobs C, Holtappels M, Toda M, Verweij P, Wauters J.

International survey on influenza-associated pulmonary aspergillosis (IAPA)

in intensive care units: responses suggest low awareness and potential

underdiagnosis outside Europe. Crit Care. 2020;24(1):84. https://doi.org/10.

1186/s13054-020-2808-8.

2. Sarwar M, Gardezi SAH, Zaman G, Ikram A, Satti L, Khadim MT. Evaluation of galactomannan and beta-d-glucan assays for the diagnosis of invasive aspergillosis in clinically suspected cases. J Pak Med Assoc. 2020;70(3):442-6. https://doi.org/10.5455/JPMA.1476.

3. Bassetti $M$, Peghin M, Vena A. Challenges and solution of invasive aspergillosis in non-neutropenic patients: a review. Infect Dis Ther. 2018;7: 17-27.

4. Sulahian A, Porcher R, Bergeron A, Touratier S, Raffoux E, Menotti J, et al Use and limits of (1-3)-beta-d-glucan assay (Fungitell),compared to galactomannan determination (Platelia Aspergillus),for diagnosis of invasive aspergillosis. J Clin Microbiol. 2014;52:2328-33.

\section{Publisher's Note}

Springer Nature remains neutral with regard to jurisdictional claims in published maps and institutional affiliations. 